\title{
Why Should We be More Concerned for the Female Athlete about High Impact Sports and Urinary Incontinence
}

\author{
Soraia de Jesus Rosa Coelho* \\ Center for Physiotherapy, Egas Moniz School of Health, Portugal \\ Submission: February 19, 2017; Published: March 01, 2017 \\ *Corresponding author: Soraia de Jesus Rosa Coelho, Physiotherapy in Women's Health, Center for Physiotherapy, Egas Moniz School of Health, \\ Portugal, Email: suraya.rosa@gmail.com
}

Keywords: Female athletes; Pelvic floor dysfunction; Epidemiology; Women's health; Urinary incontinence

Abbreviations: SUI: Stress Urinary Incontinence; ISD: Intrinsic Sphincter Deficiency; PFM: Pelvic Floor Muscles; UI: Urinary Incontinence; PF: Pelvic Floor

\section{Introduction}

My week started with another female athlete telling me it's perfectly normal to lose urine while running. "No big deal", she said. "All of my team mates go through the same. Just means we are doing a great work out, right?" Wrong. This couldn't be further from the truth.

In my line of practice, I do see more and more female athletes, always with the same set of health problems, with little attention given to the impact of UI on the daily life of athletes.

As we know, the female pelvic floor is formed by a set of muscles, fasciae, and ligaments that sustain the pelvic organs, as well as appropriately closure/opening mechanism of the urethra, vagina, and anus. High intensity exercises can be damaging to the muscles and fascia set, leading to urinary incontinence.

Stress urinary incontinence (SUI) has an observed prevalence of between $4 \%$ and $35 \%$ [1]. It is fairly common and affects many women globally. About $50 \%$ of women with urinary incontinence report symptoms of stress incontinence [2]. Specifically, there are two types of SUI: urethral hyper mobility and intrinsic sphincter deficiency (ISD). In the case of urethral hyper mobility, the urethra shifts positions with an increase in abdominal pressure, allowing urine to exit the bladder.

Stress urinary incontinence is usually associated with weak pelvic floor muscles (PFM) coupled with too much pressure. This can also be complicated by factors such as extra abdominal weight, pelvic organ prolapses and chronic constipation. Therefore, it is likely that female athletes involved in high-impact and in strong effort activities (running, cross fit, gymnastics, etc...) are at risk for the occurrence of urinary incontinence (UI).

\section{Here are some of the statistics and facts.}

The prevalence of UI in athletes varies widely, being directly associated not only with the high impact but also with the intensity of the physical activity. Authors have demonstrated that high-impact sport activities are associated to stress UI in nulliparous women who have competed for prolonged periods [3]. Trampolinists seem to be at highest risk for UI by $80 \%$ [4].

Urine loss in athletes seems to be related to how frequently women are subjected to increased intra-abdominal pressure, which is caused by a contraction of the abdominal muscles in high-impact and strengthening activities without proper awareness of the pelvic floor muscles (PFM). Active physical activity that increases intra-abdominal pressure can strain and damage the perineum and decrease the contraction force of the PFM. The more frequent the impact associated with increased intra-abdominal pressure, the greater the need for restraint and support of the pelvic organs by the PFM, which must be trained to preserve their function [5].

A significant number of elite female athletes have symptoms of stress urinary incontinence [6] reported that because of sudden intra-abdominal pressure increases, pelvic floor muscles needed to be much stronger in elite athletes than in nonathlete, while Silva, et al. [7] suggested that perineal pressure was decreased in female athletes compared to non-athlete women. A lower perineal pressure correlates with increased symptoms of urinary incontinence and pelvic floor dysfunction. In a retrospective cohort study of female Olympians, Nygaard [8] found that $35 \%$ of Olympic track and field participants had urinary leakage while competing at the Olympic Games. 


\section{So why all of these statistics are relevant?}

This stress the need to train the correct contraction of PFM, especially during high impact and strength-related sport activities to guard connective tissue from overstretching, since more than $30 \%$ of women cannot contract their pelvic floor (PF) muscles correctly because these muscles are rarely consciously used [9].

Female athletes with UI symptoms use strategies such as wearing absorbent pads, urinating before practice, reducing liquid intake, adapting athletic technique, or even bypassing sports to minimize the consequences of this condition [3]. These findings suggest that participants are not aware of treatment options for UI, thus, as stated previously, do not commonly seek treatment or professional advice [5]. This may induce these women to miss optimal timing to address UI and pelvic floor muscle training. In the future, UI and other PF dysfunctions will negatively impact the quality of life of those women and increase their health-related costs [10]. Therefore, it seems needed to establish an approach to technical staff and female athletes concerning preventive and treatment options for such dysfunctions.

Conservative treatment with a women's health physiotherapists one of the best options. They train extensively in helping patients with SUI with a very high success rates. Davila [11] revealed that pelvic floor rehabilitation can yield benefits that persist in some patients for at least 12 months.

A variety of techniques and approaches are used. With a conservative approach by a women's health physiotherapist, the athlete will be taught to contract the right muscles of the pelvic floor and sphincters. The pelvic floor does not function in isolation. Said that, the physiotherapist must consider the bowel and bladder function, strength, length and/or function of the diaphragm, deep back and abdominal muscles, gluteal muscles, breathing, surgical history, fitness level, etc.
The physiotherapist helps recuperate the function of all of the supporting muscles, improve movement and form for all exercises to decrease stress/excess pressure to the pelvic floor, and provide education regarding bowel and bladder habits that can have a major impact on the athlete progress.

\section{References}

1. Luber KM (2004) The Definition, Prevalence, and Risk Factors for Stress Urinary Incontinence. Rev Urol 6(Suppl 3): S3-S9.

2. Reynolds WS, Dmochowski R, Penson D (2011) Epidemiology of stress urinary incontinence in women. Cur Urol Rep 12(5): 370-376.

3. Thyssen H, Clevin L, Olesen S, Lose G (2002) Urinary incontinence in elite female athletes and dancers. Int Urogynecol J Pelvic Floor Dysfunct 13(1): 15-17.

4. Eliasson K, Larsson T, Mattsson E (2002) Prevalence of stress incontinence in nulliparous elite trampolinists. Scand J Med Sci Sports 12(2): 106-110.

5. Carls C (2007) The prevalence of stress urinary incontinence in high school and college age female athletes in the Midwest: implications for education and prevention. Urol Nurs 27(1): 21-24.

6. Bo K (2004) Pelvic Floor muscle training is effective in treatment of female stress urinary incontinence, but how does it work? Int Urogynecol J pelvic Floor Dysfunct 15(2): 76-84.

7. Silva L, Nunes F, Oliveira E (2013) Assessment of pelvic floor muscle pressure in female athletes. PMR 5(3): 189-193.

8. Nygaard I (1997) Does Prolonged High-impact Activity Contribute to Later Urinar Incontinence? A Retrospective Cohort Study of Female Olympians. Obstetrics Gynecol 90(5): 718-722.

9. Bo K, Sherburn M (2005) Evaluation of female pelvic-floor muscle function and strength. Phys Ther 85(3): 269-282.

10. MacLennan A, Taylor A, Wilson D, Wilson D (2000) The prevalence of pelvic floor disorders and their relationship to gender, age, parity and mode of delivery. BJOG 107(12): 1460-1470.

11. Davila GW (2011) Non-surgical Outpatient Therapies for the Management of Female Stress Urinary Incontinence: Long-Term Effectiveness and Durability. Adv Urol 2011: 176498.

Your next submission with Juniper Publishers will reach you the below assets

- Quality Editorial service

- Swift Peer Review

- Reprints availability

- E-prints Service

- Manuscript Podcast for convenient understanding

- Global attainment for your research

- Manuscript accessibility in different formats

( Pdf, E-pub, Full Text, Audio)

- Unceasing customer service

Track the below URL for one-step submission https://juniperpublishers.com/online-submission.php 